\title{
ON THE OPTIMALITY OF NOT ALLOCATING
}

\section{Angel Hernando-Veciana Fabio Michelucci}

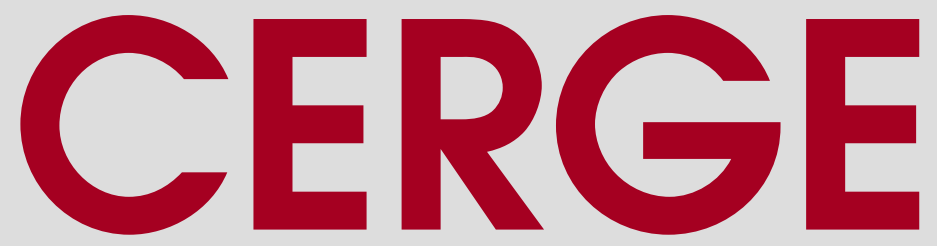




\title{
Working Paper Series $\quad 514$ (ISSN 1211-3298)
}

\section{On the Optimality of Not Allocating}

\author{
Angel Hernando-Veciana \\ Fabio Michelucci
}

CERGE-EI

Prague, July 2014 
ISBN 978-80-7343-318-5 (Univerzita Karlova. Centrum pro ekonomický výzkum a doktorské studium)

ISBN 978-80-7344-311-5 (Akademie věd České republiky. Národohospodářský ústav) 


\title{
On the Optimality of Not Allocating*
}

\author{
Ángel Hernando-Veciana ${ }^{\dagger}$ \\ Universidad Carlos III de Madrid
}

Fabio Michelucci ${ }^{\ddagger}$

CERGE-EI

July 11, 2014

\begin{abstract}
We show that the commitment to not allocate may be exploited by a seller/social planner to increase the expected social surplus that can be achieved in the sale of an indivisible unit.
\end{abstract}

\begin{abstract}
Abstrakt
Ukazujeme, že závazek nealokovat může být zneužitý prodejcem/sociálním plánovačem k zvýšení očekávaného společenského přebytku, který může být dosažen prodejem nedělitelné jednotky.
\end{abstract}

JEL Classification Numbers: D44, D82.

Keywords: Efficiency; Auctions; Mechanism design.

\footnotetext{
*We would like to thank Jacob Goeree and Philippe Jehiel for helpful discussions.

†Department of Economics. Universidad Carlos III de Madrid. c/ Madrid, 126. 28903 Getafe (Madrid) SPAIN. Email: angel.hernando@uc3m.es URL: http://www.eco.uc3m.es/ahernando/

${ }^{\ddagger}$ Corresponding author: Fabio Michelucci, CERGE-EI, P.O. Box 882 Politickych veznu 711121 Praha 1 Czech Republic. Email: fabio.michelucci@cerge-ei.cz. CERGE-EI, a joint workplace of Charles University and the Economics Institute of the Academy of Sciences of the Czech Republic, Politickych veznu 7, 11121 Prague, Czech Republic.
} 


\section{Introduction}

This note illustrates a novel strategic use of the option of not allocating. It has been well known since Myerson (1981) that in order to maximize revenues, the optimal mechanism may require the seller to retain the object. In a setting with externalities, Jehiel, Moldovanu, and Stacchetti (1996) have shown that the seller may be better off not selling at all. In the bargaining literature, it is known that the option of value destruction can be strategically exploited to improve the buyer's bargaining position; see for instance Dasgupta and Maskin (2007). A common feature of the above papers is that not allocating, or voluntary destroying value, are instruments used by one of the participants in the mechanism to increase his/her own surplus at the expense of that of some other party. Instead, we point out that not allocating can be a tool to increase expected social surplus. This work is part of our research agenda on second best efficiency; see our companion papers Hernando-Veciana and Michelucci (2011), and Hernando-Veciana and Michelucci (2013). Our approach differs from most of the literature on efficient auctions, which focuses on environments where the first best allocation is feasible; see Maskin (2003) for a review. From a technical point of view, we adapt the ironing techniques introduced by Myerson (1981) to characterize the second best allocation.

\section{The Model}

One unit of an indivisible good is put up for sale to a set of 2 potential buyers. The seller's value is assumed to be zero. Let $s=\left(s_{1}, s_{2}\right) \in \mathbb{R}^{2}$ be a vector where $s_{i}$ corresponds to the realization of an independent random variable with distribution $F_{i}$ and with a strictly positive density in a bounded support $S_{i} \subset \mathbb{R}$. Buyer $i \in 1,2$ privately observes $s_{i}$ and gains a von Neumann-Morgenstern utility $v_{i}(s)-p$ if she gets the good for sale at price $p$, and utility $-p$ if she does not get the good and pays a price $p$. We assume that $v_{i}(s)=s_{i}+\alpha s_{j}$, for any $i \in\{1,2\}$, where $\alpha>1$. To further simplify the notation, we assume that $F$ is a Uniform distribution, and $S_{i}=[0,1]$. The restriction to $\alpha>1$ is commented upon the next section. 


\section{$3 \quad$ Feasible Allocations and First Best Efficiency}

We are interested in the set of allocations that can be implemented. According to the revelation principle, there is no loss of generality when restricting to direct mechanisms. A direct mechanism is a pair of measurable functions $(p, x)$, where $p$ is an allocation and $x: S \rightarrow \mathbb{R}^{2}$ a payment function. Let an allocation be a measurable function $p: S \rightarrow[0,1]^{2}$, where $S \equiv \prod_{i \in\{1,2\}} S_{i}, \sum_{i \in\{1,2\}} p_{i}(s) \leq 1$, and where $p_{i}(s)$ denotes the probability that the good is allocated to $i$ when the vector of types is $s \in S$. We say that an allocation $p$ is feasible if a direct mechanism $(p, x)$ exists that satisfies the following Bayesian incentive compatibility constraint: $U_{i}\left(s_{i}, s_{i}\right)=\sup _{s_{i}^{\prime} \in S_{i}}\left\{U_{i}\left(s_{i}, s_{i}^{\prime}\right)\right\}$, for all $s_{i} \in S_{i}$ and any $i$, where,

$$
U_{i}\left(s_{i}, s_{i}^{\prime}\right) \equiv \int_{S_{j}}\left(v_{i}(s) p_{i}\left(s_{i}^{\prime}, s_{j}\right)-x_{i}\left(s_{i}^{\prime}, s_{j}\right)\right) d s_{j} .
$$

Lemma 1. An allocation $p$ is feasible if and only if $Q_{i}\left(s_{i}, p\right) \equiv \int_{S_{j}} p_{i}\left(s_{i}, s_{j}\right) d s_{j}$ is weakly increasing in $s_{i}, \forall i$.

Proof. See Myerson (1981).

We rewrite $v_{i}(s)$ in a way that is convenient for the second best analysis: $v_{i}(s)=\alpha\left(s_{i}+\right.$ $\left.s_{j}\right)+h_{i}\left(s_{i}\right)$, where $h_{i}\left(s_{i}\right) \equiv-(\alpha-1) s_{i}{ }^{1}$

Definition: We say that an allocation $p$ is first best efficient when it satisfies for any $s \in S$ that $\sum_{i=1}^{2} p_{i}(s)=1$, and $p_{i}(s)>0$ only if $h_{i}\left(s_{i}\right)=\max \left\{h\left(s_{j}\right)\right\}_{j=1}^{2}$.

\section{Second Best Efficiency and the Optimality of Not Al- locating}

In our environment the unique symmetric equilibrium of standard auctions (e.g. FPA, SPA, EA) allocates the good to the buyer with highest type, who is the buyer with lowest value.

\footnotetext{
${ }^{1}$ From this way of rewriting the problem, it is also possible to appreciate that one can reinterpret the setting we present as one where buyers share a common value $\alpha \sum_{i \in N} s_{i}$ for the object, and where buyer $i$ imposes (when winning) a negative externality on the other buyer equal to $h_{i}\left(s_{i}\right)$.
} 
Consequently, standard auctions implement the allocation that induces the lowest expected surplus among the allocations that always allocate the good to the one of the buyers.

Definition: We say that an allocation $p$ is second best efficient if it is feasible and it maximizes $\int_{S} \sum_{i=1}^{2}\left(\alpha\left(s_{i}+s_{j}\right)+h\left(s_{i}\right)\right) p_{i}(s) d s$.

The first best allocation is not implementable because $h_{i}$ is decreasing. ${ }^{2}$ We derive from the $h_{i}$ functions some auxiliary functions that we call $g_{i}$, which are non decreasing and determine the second best allocation like the $h_{i}$ 's determine the first best. Let $H_{i}\left(s_{i}\right) \equiv \int_{0}^{s_{i}} h_{i}\left(\tilde{s}_{i}\right) d \tilde{s}_{i}$ for any $i$ and any $s_{i}$, and let $G_{i}\left(s_{i}\right):[0,1] \rightarrow \mathbb{R}$ be the convex hull of the function $H_{i} \cdot{ }^{3}$ Formally:

$$
G_{i}\left(s_{i}\right)=\min \left\{w H_{i}\left(r_{1}\right)+(1-w) H_{i}\left(r_{2}\right): w, r_{1}, r_{2} \in[0,1] \text { and } w r_{1}+(1-w) r_{2}=s_{i}\right\} \text {. }
$$

Lemma 2. Properties of $G_{i}$ (see Section 6 in Myerson (1981)):

(a) $G_{i}$ is convex; (b) $G_{i}(0)=H_{i}(0)$ and $G_{i}(1)=H_{i}(1)$; (c) $G_{i}\left(s_{i}\right) \leq H_{i}\left(s_{i}\right)$ for all $s_{i} \in[0,1]$; (d) If $G_{i}\left(s_{i}\right)<H_{i}\left(s_{i}\right)$ in an open interval, then $G_{i}$ is linear in the same open interval.

As a convex function, $G_{i}$ is differentiable except at countably many points, and its derivative is a non-decreasing function. We define $g_{i}:[0,1] \rightarrow \mathbb{R}$ as the differential of $G_{i}$, wherever it exists, completed by right-continuity.

Lemma 3. A feasible allocation $p^{*}$ is second best efficient if and only if it maximizes: ${ }^{4}$

$$
\int_{S} \sum_{i=1}^{2}\left(\alpha\left(s_{i}+s_{j}\right)+g_{i}\left(s_{i}\right)\right) p_{i}(s) d s+\sum_{i=1}^{n} \int_{S_{i}}\left(G_{i}\left(s_{i}\right)-H_{i}\left(s_{i}\right)\right) Q_{i}\left(d s_{i}, p\right) .
$$

See the proof in the Appendix.

\footnotetext{
${ }^{2}$ The fact that the first best is not implementable is due to the assumption $\alpha>1$ that implies a violation of the single crossing condition; see Maskin (1992), which is a necessary condition for the implementability of the first best.

${ }^{3}$ That is the highest convex function on $[0,1]$ such that $G_{i}\left(s_{i}\right) \leq H_{i}\left(s_{i}\right)$ for all $s_{i} \in[0,1]$. See also Rockafellar (1970), Page 36.

${ }^{4}$ We denote by $\int_{E} \varphi(x) F(d x)$ the Lebesgue-Stieljes integral of $\varphi$ with respect to $F$ in $E$. In particular, for any feasible allocation $p$, we denote by $\int_{S_{i}} \varphi\left(s_{i}\right) Q_{i}\left(d s_{i}, p\right)$ the Lebesgue-Stieljes integral of $\varphi$ with respect to $Q_{i}(., p)$ in $S_{i}$.
} 
Corollary 1. Suppose that there exists ${ }^{5}$ a feasible allocation $p^{*}$ that satisfies:

(i) $p_{i}^{*}(s)>0$ only if $g_{i}\left(s_{i}\right)=\max \left\{g_{j}\left(s_{j}\right)\right\}_{j \in N}$ and $\alpha\left(s_{i}+s_{j}\right) \geq-g_{i}\left(s_{i}\right)$.

(ii) $Q_{i}\left(., p^{*}\right)$ is constant in any open interval in which $G_{i}\left(s_{i}\right)<H_{i}\left(s_{i}\right)$.

Then, a feasible allocation $p$ is second best if and only if $p=p^{*}$ a.e.

Condition (i) and (ii) are necessary and sufficient conditions for the maximization of the first and second integral in Equation (1), respectively. The former is straightforward and the latter follows from the application of Lemma 2(c) since it implies that the second integral is non-positive and that (ii) is a necessary and sufficient condition for the second integral to be equal to zero.

Proposition 1. The following symmetric allocation rule is feasible, and maximizes the expected social surplus:

- If $s_{1}+s_{2} \leq \frac{(\alpha-1)}{2 \alpha}$, then $p_{1}\left(s_{1}, s_{2}\right)=p_{2}\left(s_{1}, s_{2}\right)=0$.

- If $s_{1}, s_{2}>\frac{(\alpha-1)}{2 \alpha}$, or if $s_{1}, s_{2}<\frac{(\alpha-1)}{2 \alpha}$ and $s_{1}+s_{2}>\frac{(\alpha-1)}{2 \alpha}$, then $p_{1}\left(s_{1}, s_{2}\right)=p_{2}\left(s_{1}, s_{2}\right)=\frac{1}{2}$.

- If $s_{1} \leq \frac{(\alpha-1)}{2 \alpha}$ and $s_{2} \geq \frac{(\alpha-1)}{2 \alpha}$, then $p_{1}\left(s_{1}, s_{2}\right)=\frac{7 \alpha^{2}+2 \alpha-1}{8 \alpha(\alpha+1)}-\frac{\alpha}{\alpha+1} s_{1}$ and $p_{2}\left(s_{1}, s_{2}\right)=1$ $p_{1}\left(s_{1}, s_{2}\right)$.

- If $s_{1} \geq \frac{(\alpha-1)}{2 \alpha}$ and $s_{2} \leq \frac{(\alpha-1)}{2 \alpha}$, then $p_{2}\left(s_{1}, s_{2}\right)=\frac{7 \alpha^{2}+2 \alpha-1}{8 \alpha(\alpha+1)}-\frac{\alpha}{\alpha+1} s_{2}$ and $p_{1}\left(s_{1}, s_{2}\right)=1$ $p_{2}\left(s_{1}, s_{2}\right)$.

Proof. The allocation is feasible by application of Lemma 1 because $Q_{i}\left(s_{i}, p\right)=\frac{7 \alpha^{2}+2 \alpha-1}{16 \alpha^{2}}$ for $s_{i} \in[0,1]$ and $i \in\{1,2\}$. To finish the proof, we check that the allocation also satisfies the conditions in Corollary 1. That $h_{i}\left(s_{i}\right)=-(\alpha-1) s_{i}$ implies that $g_{i}\left(s_{i}\right)=-\frac{\alpha-1}{2}$. Thus, condition

\footnotetext{
${ }^{5}$ That such $p^{*}$ exists under our assumptions is shown below. However, this is not true under other alternative assumptions in which Corollary 1 still applies. This is the case of $v_{1}\left(s_{1}, s_{2}\right)=s_{1}+2 s_{2}+\epsilon$ and $v_{2}\left(s_{1}, s_{2}\right)=s_{2}+2 s_{1}$ for $\epsilon>0$ and small, and $s_{1}, s_{2} \in[0,1]$. In this example, Corollary 1 implies that $p^{*}(s)=(0,0)$ if $s_{1}+s_{2}<\frac{1}{4}-\frac{\epsilon}{2}$, and $p^{*}(s)=(1,0)$, otherwise. But such $p^{*}$ does not satisfy Corollary 1(ii). To see why, note that $Q_{1}\left(s_{1}, p^{*}\right)$ is strictly increasing in $s_{1} \in\left(0, \frac{1}{4}-\frac{\epsilon}{2}\right)$ and one can argue as in the proof of Proposition 1 that $G_{1}\left(s_{1}\right)<H_{1}\left(s_{1}\right)$ for any $s_{1} \in(0,1)$.
} 
(i) is equivalent to $p_{1}(s)+p_{2}(s)>0$ if and only if $s_{1}+s_{2} \geq \frac{(\alpha-1)}{2 \alpha}$, which is satisfied by the proposed allocation. Condition (ii) is also satisfied because $Q_{i}\left(s_{i}, p\right)=\frac{7 \alpha^{2}+2 \alpha-1}{16 \alpha^{2}}$ for any $i$ and any $s_{i}$, which is constant in $s_{i}$.

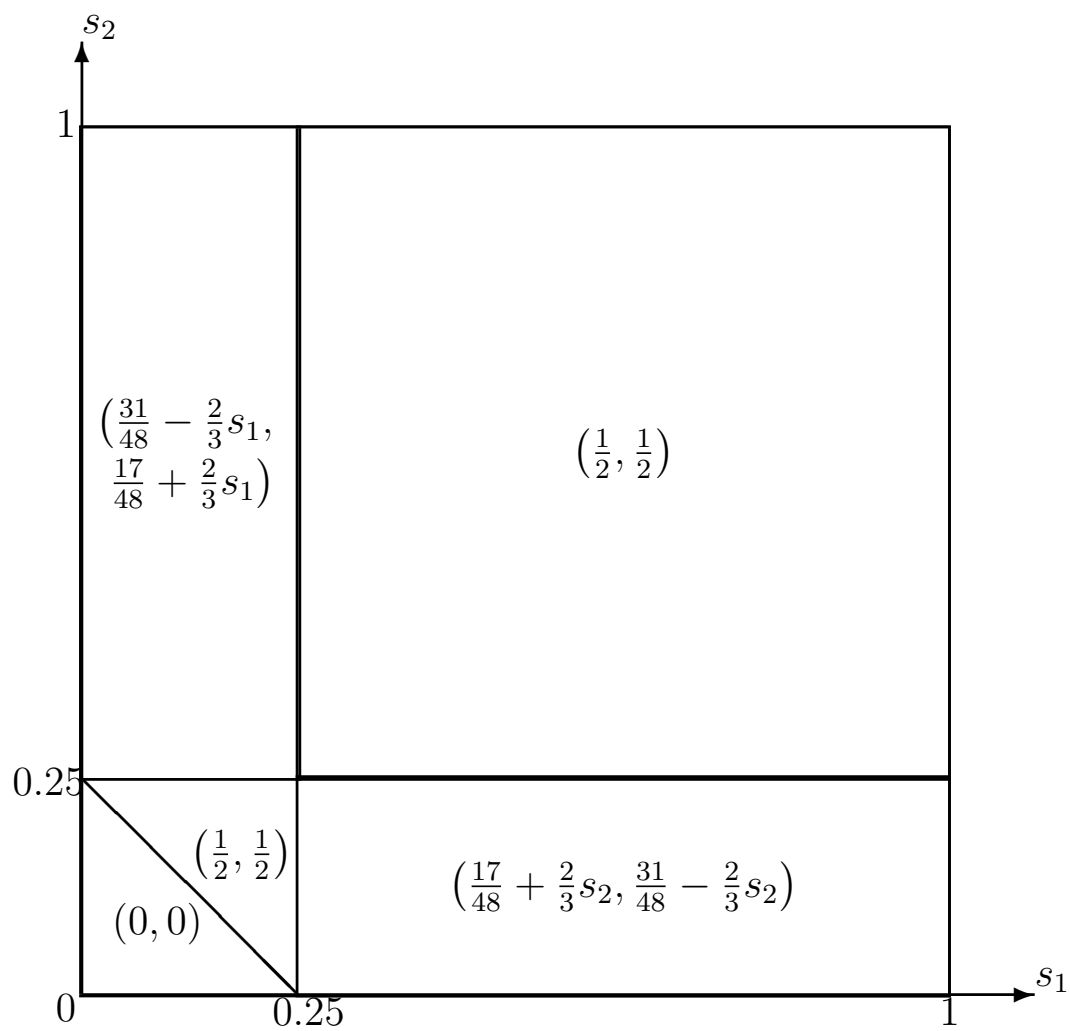

Figure 1: Second best allocation $\left(p_{1}(s), p_{2}(s)\right)$ for $\alpha=2$, i.e. $v_{i}\left(s_{i}, s_{j}\right)=s_{i}+2 s_{j}$

Figure 1 illustrates the second best allocation for $\alpha=2 .{ }^{6}$ We can easily compare this allocation to an allocation that maximizes expected surplus subject to always selling, i.e. $p_{1}(s)+$ $p_{2}(s)=1$ for all $s \in S$. One example of the latter is the uniformly random allocation that assigns the good with equal probability to either buyers (independently of their report). ${ }^{7}$ Switching

\footnotetext{
${ }^{6}$ Gershkov, Goeree, Kushnir, Moldovanu, and Shi (2013) applies our insights on the structure of the second best when $\alpha=2$ to show that Bayesian incentive compatible mechanisms can provide strictly larger expected surplus than any ex post incentive compatible mechanism in a model with two types.

${ }^{7}$ To see why, note that the uniformly random allocation maximizes both integrals in Equation (1) under the
} 
from the uniformly random allocation to the second best allocation increases the expected social surplus because the efficiency loss of not allocating the good to any buyer in the triangle is small relative to the efficiency gain that can be achieved in the rectangle areas.

Corollary 2. No standard auction with an entry fee or a reserve price implements the second best.

Corollary 2 is a direct consequence of Corollary $1(\mathrm{i})$ because $\left\{\left(s_{1}, s_{2}\right): \alpha\left(s_{1}+s_{2}\right)<-g_{i}\left(s_{i}\right)\right\}$ is a triangular subset of the space of types since $g_{i}\left(s_{i}\right)=\frac{\alpha-1}{2}$, and there is no equilibrium of standard auctions with entry fees or reserve prices in which the set of types that do not participate is triangular. Note that this would require the participation decision of one buyer to be conditional on the type of another buyer, which is not a feasible strategy in a standard auction.

\section{Conclusions}

We provide a novel rationale for a seller/social planner to credibly commit to retain the object. Interestingly, reserve price and entry fees are not helpful in implementing the most efficient allocation because they are not conditional on the type (or bid) of all the buyers.

constraint that $p_{1}(s)+p_{2}(s)=1$ for any $s \in S$. This can be deduced from the fact that $p_{1}(s)+p_{2}(s)=1$ implies that the first integral in Equation (1) is constant and equal to $\alpha-\frac{\alpha-1}{2}$, since $g_{i}\left(s_{i}\right)=-\frac{\alpha-1}{2}$, and the second integral is zero for the uniformly random allocation, and as we have already explained, the second integral never takes a strictly positive value because of Lemma $2(\mathrm{c})$. 


\section{A Proofs}

\section{Proof of Proposition 1}

Proof. The second best maximizes:

$$
\int_{S} \sum_{i=1}^{2} v_{i}(s) p_{i}(s) d s=\int_{S} \sum_{i=1}^{2}\left(\sum_{j=1}^{2} s_{j}+h_{i}\left(s_{i}\right)\right) p_{i}(s) d s .
$$

Moreover, note that:

$$
\begin{gathered}
\int_{S}\left(h_{i}\left(s_{i}\right)-g_{i}\left(s_{i}\right)\right) p_{i}(s) d s=\int_{0}^{1}\left(h_{i}\left(s_{i}\right)-g_{i}\left(s_{i}\right)\right) Q_{i}\left(s_{i}, p\right) d s_{i}= \\
\int_{0}^{1} Q_{i}\left(s_{i}, p\right) H_{i}\left(d s_{i}\right)-\int_{0}^{1} Q_{i}\left(s_{i}, p\right) G_{i}\left(d s_{i}\right)= \\
-\int_{0}^{1}\left(H_{i}\left(s_{i}\right)-G_{i}\left(s_{i}\right)\right) Q_{i}\left(d s_{i}, p\right) .
\end{gathered}
$$

where we use the definition of $Q_{i}$ and $S_{i}$ in the first step, in the second step, $H_{i}^{\prime}\left(s_{i}\right)=h_{i}\left(s_{i}\right)$ and $G_{i}^{\prime}\left(s_{i}\right)=g_{i}\left(s_{i}\right)$ a.e., and in the third step, integration by parts and Lemma 2(b).

Consequently, the expressions in Equation (2) are equal to the expression in Equation (1) as desired. 


\section{References}

Dasgupta, P., And E. S. Maskin (2007): "Bargaining and Destructive Power," Annals of Economic and Finance, pp. 217-227.

Gershkov, A., J. K. Goeree, A. Kushnir, B. Moldovanu, and X. Shi (2013): "On the Equivalence of Bayesian and Dominant Strategy Implementation," Econometrica, 81(1), $197-220$.

Hernando-Veciana, A., and F. Michelucci (2011): "Second Best Efficiency and The English Auction," Games and Economic Behavior, 73(2), 496-506.

(2013): "Do Not Panic: How to Avoid Inefficient Rushes Using Multi-Stage Auctions," CERGE-EI Working Paper 489.

Jehiel, P., B. Moldovanu, And E. Stacchetti (1996): "How (Not) to Sell Nuclear Weapons," The American Economic Review, 86(4), 814-829.

Maskin, E. (1992): "Auctions and Privatization," in Privatization: Symposium in honour of Herbert Giersh, ed. by H. Siebert. Institute fur Weltwirtshaft an der Univarsitat Kiel.

- (2003): "Auctions and Efficiency," in Advances in Economics and Econometrics: Theory and Applications: 8th World Congress (Econometric Society Monographs, ed. by M. Dewatripont, L. Hansen, and S. Turnovsky. Cambridge University Press.

Myerson, R. B. (1981): "Optimal Auction Design," Mathematics of Operation Research, $6(1), 58-73$.

Rockafellar, R. T. (1970): Convex Analysis. Princeton University Press. 


\section{Working Paper Series}

ISSN 1211-3298

Registration No. (Ministry of Culture): E 19443

Individual researchers, as well as the on-line and printed versions of the CERGE-EI Working Papers (including their dissemination) were supported from institutional support RVO 67985998 from Economics Institute of the ASCR, v. v. i.

Specific research support and/or other grants the researchers/publications benefited from are acknowledged at the beginning of the Paper.

(c) Angel Hernando-Veciana and Fabio Michelucci, 2014

All rights reserved. No part of this publication may be reproduced, stored in a retrieval system or transmitted in any form or by any means, electronic, mechanical or photocopying, recording, or otherwise without the prior permission of the publisher.

Published by

Charles University in Prague, Center for Economic Research and Graduate Education (CERGE) and

Economics Institute of the ASCR, v. v. i. (EI)

CERGE-EI, Politických vězňů 7, 11121 Prague 1, tel.: +420 224005 153, Czech Republic.

Printed by CERGE-EI, Prague

Subscription: CERGE-EI homepage: http://www.cerge-ei.cz

Phone: + 420224005153

Email: office@cerge-ei.cz

Web: http://www.cerge-ei.cz

Editor: Marek Kapička

The paper is available online at http://www.cerge-ei.cz/publications/working_papers/.

ISBN 978-80-7343-318-5 (Univerzita Karlova. Centrum pro ekonomický výzkum a doktorské studium)

ISBN 978-80-7344-311-5 (Akademie věd České republiky. Národohospodářský ústav) 
CERGE-EI

P.O.BOX 882

Politických vězňů 7

11121 Praha 1

Czech Republic http://www.cerge-ei.cz 